\title{
Spring Growth and Use of Cool-Season Graminoids in the Nebraska Sandhills
}

\author{
Jerry D. Volesky, ${ }^{1}$ Walter H. Schacht, ${ }^{2}$ \\ Patrick E. Reece, ${ }^{3}$ and Timothy J. Vaughn ${ }^{4}$ \\ Authors are ${ }^{1}$ Associate Professor, University of Nebraska-Lincoln, West Central Research and Extension Center, North Platte, \\ NE 69101; ${ }^{2}$ Associate Professor, Agron and Hort Dept, University of Nebraska-Lincoln, Lincoln, NE 68583; ${ }^{3}$ Professor, \\ University of Nebraska-Lincoln, Panhandle Research and Extension Center, Scottsbluff, NE 69361; and ${ }^{4}$ former Graduate \\ Research Assistant, 14460 N Sand Rd, Hershey, NE 69143.
}

\begin{abstract}
Upland sites in the Nebraska Sandhills are dominated by warm-season grasses, although cool-season graminoids often produce from $10 \%$ to $40 \%$ of the herbage. The grazing season on uplands traditionally begins when warm-season grasses have initiated rapid growth, which coincides with declining nutrient density of cool-season plants. Earlier initiation of grazing would improve the efficiency of use of cool-season plants. A study was conducted in 2001 and 2002 to characterize the growth of cool-season species on upland range and to determine the use and herbage production in response to spring grazing date and stocking rate. Grazing dates were 10 April, 1 May, and 22 May, combined with stocking rates of 3, 6, and 9 AUD (animal unit days) $\cdot$ ha $^{-1}$. Needleandthread (Stipa comata Trin. \& Rupr.) and sedges (Carex spp.) accounted for an average of $48 \%$ of the spring herbage yield. Amount of total current-year herbage ranged from 114 to $472 \mathrm{~kg} \cdot \mathrm{ha}^{-1}$ over the grazing dates. Overall, paddock use of needleandthread and sedges averaged $11 \%$ and $4 \%$, respectively. Use on 10 April averaged $61 \%$ of that observed on 1 and 22 May, likely because of short plant height $(5 \mathrm{~cm})$. Residual (prior-year) herbage probably was a substantial component of animal diets on 10 April. Increasing stocking rate resulted in greater herbage use (\% weight removed) and percentage of plants grazed $(P<0.1)$. Total herbage yield in mid-June $\left(1130 \mathrm{~kg} \cdot \mathrm{ha}^{-1}\right)$ and mid-August $\left(1350 \mathrm{~kg} \cdot \mathrm{ha}^{-1}\right)$ was greatest when paddocks were grazed in April, and it declined by approximately $20 \%$ when grazed in May $(P<0.1)$. Overall, upland grazing strategies that include a grazing period in early May will result in greater utilization of cool-season species, but summer yield will be reduced. However, utilization of cool-season species in the spring would be advantageous, because they are being consumed at a time when their nutritive value and palatability are greater.
\end{abstract}

\section{Resumen}

Los sitios altos de los pastizales Sandhills de Nebraska están dominados pos zacates de estación caliente, aunque, las gramíneas de estación fría a menudo producen del $10 \%$ al $40 \%$ del forraje. En los sitios altos, la estación de apacentamiento tradicionalmente inicia cuando los zacates de estación caliente han iniciado el crecimiento rápido, lo cual coincide con la disminución de la densidad de nutrientes de las plantas de estación fría. Iniciar el apacentamiento más temprano pudiera mejorar la eficiencia de uso de las plantas de estación fría. Se condujo un estudio en 2001 y 2002 para caracterizar el crecimiento de especies de estación fría en un pastizal de sitios altos y determinar el uso y producción de forraje en respuesta a la fecha de apacentamiento en primavera y la carga animal. Las fechas de apacentamiento fueron 10 de Abril, 1 y 22 de Mayo combinadas con cargas animal de 3, 6 y 9 $\mathrm{UAD} \cdot \mathrm{ha}^{-1}$. El zacate "Needleandthread" (Stipa comata Trin. \& Rupr.) los juncos (Carex spp.) aportaron en promedio $48 \%$ del rendimiento de forraje en primavera. La cantidad forraje del total de producido en el año varió de $114 \mathrm{a} 472 \mathrm{~kg} \cdot \mathrm{ha}{ }^{-1}$ a través de la fechas de apacentamiento. En general, el uso en los potreros del "Needleandthread" y juncos promedio $11 \%$ y $4 \%$ respectivamente. El uso en el 10 de Abril promedio $61 \%$ de lo observado en el 1 y 22 de Mayo, probablemente debido a la corta altura de las plantas $(5 \mathrm{~cm}$ ). En el 10 de Abril, el forraje residual (de años pervios) fue probablemente un componente substancial en la dieta de los animales. Aumentar la carga animal resulto en un mayor uso del forraje (porcentaje del peso removido) y porcentaje de plantas apacentadas $(P<0.1)$. El mayor rendimiento total de forraje a mediados de Junio $\left(1130 \mathrm{~kg} \cdot \mathrm{ha}{ }^{-1}\right) \mathrm{y}$ mediados de Agosto (1 $\left.350 \mathrm{~kg} \cdot \mathrm{ha}^{-1}\right)$ se obtuvo cuando los potreros se apacentaron en Abril y disminuyo en aproximadamente $20 \%$ cuando se apacentaron en Mayo $(P<0.1)$. En general, las estrategias de apacentamiento de los sitios altos que incluyen un periodo de apacentamiento a inicios de Mayo resultaran en la mayor utilización de les especies de estación fría, pero el rendimiento en verano será reducido. Sin embargo, la utilización de especies de estación fría en la primavera sería ventajosa porque ellas estarán siendo consumidas en el tiempo cuando su valor nutritivo y gustocidad son mayores.

Key Words: extended grazing, herbage yield, spring grazing, utilization, warm-season grasses

This research was a portion of the fourth author's MS degree work, Agron and Hort Dept, University of Nebraska-Lincoln.

A contribution of the University of Nebraska Agricultural Research Division, Lincoln, Nebr Journal Series No. 14721. This research was supported in part by funds provided through the Hatch Act and the Anna H. Elliott Fund.

Correspondence: Jerry D. Volesky, West Central Research and Extension Center, 461 West University Dr, North Platte, NE 69101. Email: jvolesky1@unl.edu

Manuscript received 16 August 2004; manuscript accepted 16 March 2005. 


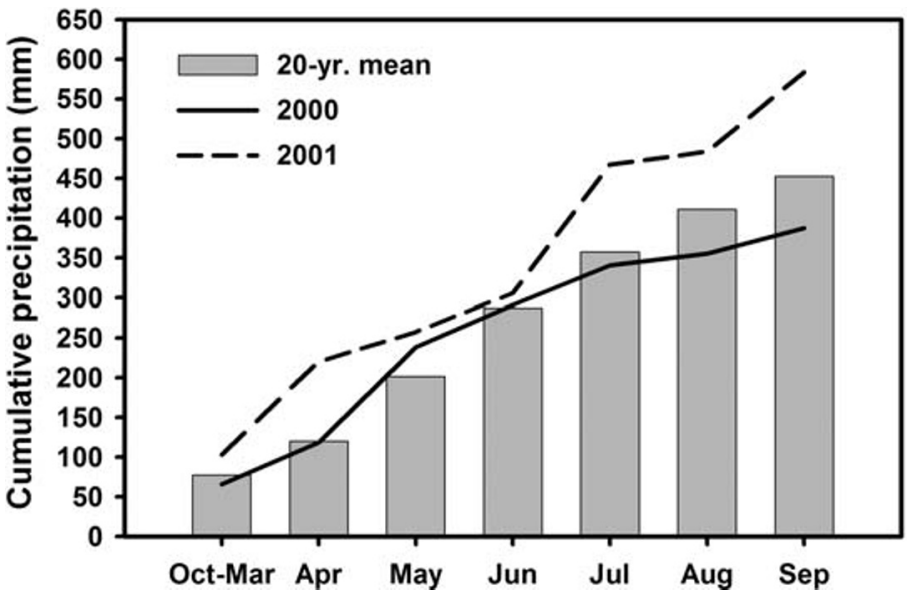

Figure 1. Cumulative plant-year (October-September) precipitation for the years 2000 and 2001 and the 20-year mean at the Gudmundsen Sandhills Laboratory near Whitman, Nebraska.

\section{INTRODUCTION}

The Nebraska Sandhills cover approximately 4.8 million ha in the central and western part of the state (Bleed and Flowerday 1998) and support approximately 1.5 million beef cattle. Vegetation of upland range is dominated by warm-season grasses (Bragg and Steuter 1995). These warm-season grasses contribute from $60 \%$ to $90 \%$ of the primary productivity on upland sites. Cool-season grasses and sedges are the principal plants that provide the other $10 \%-40 \%$ of the primary production on upland range. These plants typically begin growing in late March to mid-April, 1 month before the initiation of warmseason grass growth.

Coinciding with the growth pattern and dominance of warmseason grasses, the primary period for upland range grazing begins in mid-May and lasts through mid-October (Coady and Clark 1993). Cool-season plants can extend the grazing season, because their growing seasons complement those of the dominant warm-season grasses. Grazing upland range before midMay improves profitability, because the practice capitalizes on growth of cool-season species and reduces the amount of hay fed (Adams et al. 1994, 2001).

Timing and intensity are key variables affecting plant response to defoliation (Heady 1974). Grass productivity and survival are sensitive to different stocking rates and dates of grazing in the spring because of the morphology and physiology of the grazed plants. Defoliation at an early vegetative stage, for example, may affect carbohydrate replenishment and subsequent plant production (Coyne et al. 1995; Manske 1999). Defoliation at the elongation stage also may negatively impact plant survival and productivity (McClean and Wilkeem 1985; Mousel et al. 2003). Considerable research has been conducted on different aspects of summer defoliation patterns of the primary warm-season grass species by cattle in the Sandhills (Mullahey et al. 1991; Northup 1993; Reece et al. 1996; Engel et al. 1998). To our knowledge, however, no research has been conducted on growth and use of cool-season species during the spring.
The objectives of the present study were 1) to quantify yield and composition of current-year herbage on upland Sandhills range sites during the spring, 2) to determine the effects of stocking rate on use of herbage at selected spring grazing dates, and 3 ) to determine the effect of spring grazing on herbage yield in the summer. We hypothesized that increasing the stocking rates would increase the use of cool-season graminoids at a constant rate and that spring grazing would reduce the total herbage yield in the summer.

\section{MATERIAL AND METHODS}

\section{Study Site}

The present study was conducted during 2000 and 2001 at the University of Nebraska's Gudmundsen Sandhills Laboratory, located $11 \mathrm{~km}$ northeast of Whitman, Nebraska (lat $42^{\circ} 04^{\prime} \mathrm{N}$, long $101^{\circ} 26^{\prime} \mathrm{W}$; elevation, $\left.1075 \mathrm{~m}\right)$. The average maximum daily temperatures range from $2{ }^{\circ} \mathrm{C}$ in January to $32^{\circ} \mathrm{C}$ in July. Mean annual precipitation at the site is $453 \mathrm{~mm}$, approximately $75 \%$ of which occurs during the growing season from April through September. Growing season precipitation was $86 \%$ and $128 \%$ of the long-term mean in 2000 and 2001, respectively (Fig. 1).

The present study was conducted on sands-range sites (deepsands ecological site) with soils classified as Valentine fine sands (mixed, mesic Typic Ustipsamments). Study paddocks were in a pasture that had been used exclusively for dormant-season (October-March) grazing during the previous 8 years and were in good to excellent range condition. Warm-season grasses, including prairie sandreed [Calamovilfa longifolia (Hook.) Scribn.], sand bluestem [Andropogon gerardii var. paucipilus (Nash) Fern.], switchgrass (Panicum virgatum L.), and little bluestem [Schizachyrium scoparium (Michx.) Nash] were the dominant species on these sites. Major cool-season grasses were needleandthread (Stipa comata Trin. \& Rupr.), prairie junegrass [Koeleria pyramidata (Lam.) Beauv.], and Kentucky bluegrass (Poa pratensis L.). Several sedge species (Carex spp.) were present. Plant nomenclature follows that of the Great Plains Flora Association (1986).

\section{Grazing Treatments}

The present study involved 9 treatment combinations of 3 spring grazing dates and 3 stocking rates along with a nongrazed control. Grazing dates were 10 April, 1 May, and 22 May of each year. The 3 stocking rates were 3, 6, and 9 AUD (animal unit days) $\cdot \mathrm{ha}^{-1}$. These stocking rates were from $7 \%$ to $21 \%$ of a moderate stocking rate $\left(44 \mathrm{AUD} \cdot \mathrm{ha}^{-1}\right)$ for rangeland in high to good range condition. Three replications (blocks) were each comprised of four 0.62-ha pastures. Each of the 3 grazing date treatments (main plot) and a control were randomly assigned to one of the 4 pastures within a block. The three stocking rate treatments (split plots) were assigned randomly to paddocks within each grazing date pasture. Stocking rate paddocks were 0.34 ha for the 3 AUD $\cdot$ ha $^{-1}$ treatment, 0.17 ha for the 6 AUD $\cdot \mathrm{ha}^{-1}$ treatment, and 0.11 ha for the 9 AUD $\cdot \mathrm{ha}^{-1}$ treatment. Each paddock was grazed for 24 hours by 2 yearling steers weighing a total of approximately $454 \mathrm{~kg}$. Steers were grazed in an adjacent pasture when not used in the experimental paddocks. 


\section{Vegetation Measurements}

Spring Herbage Yield. Herbage yield was determined immediately before each grazing event for the 3 spring grazing dates by hand-clipping the standing vegetation to ground level in randomly located quadrats $\left(0.25 \mathrm{~m}^{2}, 25 \times 100 \mathrm{~cm}\right)$ in each stocking rate paddock. Five quadrats were clipped within the 9 AUD $\cdot \mathrm{ha}^{-1}$ paddock (smallest), 10 quadrats in the 6 AUD $\cdot \mathrm{ha}^{-1}$ paddock, and 15 quadrats in the $3 \mathrm{AUD} \cdot \mathrm{ha}^{-1}$ paddock (largest). Paddocks were experimental units, and different numbers of quadrats were clipped because of labor constraints. Clipped material was sorted into the following categories: needleandthread, western wheatgrass (Agropyron smithii Rydb.), prairie junegrass, Scribner's panicum [Dicanthelium oligosanthes (Schult.) Gould var. scribnerianum (Nash) Gould], prairie sandreed, sedges (Carex spp.), bluegrasses (Poa spp.), other cool-season grasses, other warm-season grasses, forbs, and residual herbage (prior-year growth). Kentucky bluegrass was the most common bluegrass, with lesser amounts of mutton grass [Poa fendleriana (Steud.) Vasey] and other bluegrass species. Clipped samples were bagged and oven-dried at $60^{\circ} \mathrm{C}$ to a constant weight.

Grazing pressure (AUD $\cdot \mathrm{Mg}^{-1}$ ) was calculated for each grazing date and paddock using pregrazing, current-year herbage yield. Animal weights were divided by $454 \mathrm{~kg}$ to estimate animal unit equivalents. Growing degree-days (GDD) were calculated from data recorded by an on-site weather station (Campbell Scientific, Inc, Logan, Utah) as maximum daily temperature plus minimum daily temperature divided by 2 minus base temperature $\left(0^{\circ} \mathrm{C}\right)$. Accumulation of GDD began on 1 January each year.

Plant Density and Use. Plant density, percentage of plants grazed, and percentage defoliation of grazed plants were determined after each grazing event. One, 2 , and 3 transects $(50 \mathrm{~m})$ were located in each 9,6 , and $3 \mathrm{AUD} \cdot \mathrm{ha}^{-1}$ stocking rate paddock, respectively. At 4-m intervals along each transect $(n=12)$, counts were made of live plants of the primary species within a $1-\mathrm{m}^{2}$ quadrat $(1 \times \mathrm{m})$. In addition to total number, counts were made of plants that had been defoliated during the grazing event. Tussocks were counted as plants for needleandthread, prairie junegrass, Scribner's panicum, and sedges. Individual tillers of western wheatgrass and prairie sandreed were counted as plants. Sun sedge (Carex heliophila Mack.) was the most common sedge species on the study site. A rhizomatous species, sun sedge may have 2 or more tillers forming a defined tussock and numerous single tillers $2-10 \mathrm{~cm}$ from a parent plant (Hermann 1970; Great Plains Flora Association 1986). Individual plants were defined as being at least $2 \mathrm{~cm}$ from a neighboring plant. With our methodology for sun sedge, single tillers were counted as plants because of the distance from a parent plant. Because of the relatively high density of sedges, we used a $0.25-\mathrm{m}^{2}$ quadrat nested within the $1-\mathrm{m}^{2}$ quadrat.

Concurrent with plant counts, a grazed-class method was used to estimate use ( $\%$ weight removed) of sedge and needleandthread (Schmutz et al. 1963). Five grazed-classes were used: $0=$ no grazing, $1=1 \%-25 \%$ use, $2=26 \%-40 \%$ use, $3=41 \%-70 \%$ use, and $4=$ more than $70 \%$ use. Grazedclasses were assigned to a maximum of 20 plants per quadrat of each species as they were encountered. Because of variability in spatial distribution of these species, the number of plants per quadrat ranged from 0 to more than 20 . An average of 11 sedge plants per $0.25-\mathrm{m}^{2}$ quadrat $(n=132$ per transect $)$ were assigned use classes. For needleandthread, an average of 7 plants per $1-\mathrm{m}^{2}$ quadrat $(n=84$ per transect) were assigned use classes. Before using the grazed-class method at each sampling date, reference samples were developed from height-weight curves for each of the 2 species. Percentage defoliation of grazed plants was calculated from the average percentage defoliation (use) of each grazed-class for plants that had been grazed. Percentage use for the paddock population of each species was determined by multiplying the average percentage use of each grazed-class by the percentage of grazed plants in each grazedclass and then totaling the products. For grazed-class $4(>70 \%$ use), a figure of $71 \%$ was used as the average percentage use for that class. Our observations through the course of the present study indicated that the grazing steers were physically unable to remove more than that amount. Cullan et al. (1999), in a summer-grazing study on a similar Sandhills site, reported that approximately $70 \%$ was the maximum use of prairie sandreed by cattle at high grazing pressure.

Summer Herbage Yield. Herbage yield was determined on 18 June and 15 August of each year. These dates correspond to the approximate time of peak cool- and warm-season herbage yields, respectively (Northup 1993). A total of 35 quadrats $\left(0.25 \mathrm{~m}^{2}\right)$ were hand-clipped in each grazing-date whole plot, with 10,10, and 15 quadrats from random locations within the 9,6 , and 3 AUD $\cdot \mathrm{ha}^{-1}$ stocking rate paddocks, respectively. Twenty-five quadrats were clipped to ground level from random locations in each control pasture. Clipped material was sorted into the following categories: cool-season graminoids, warmseason grasses, forbs, and residual herbage (prior-year growth). Clipped samples were bagged and oven-dried at $60^{\circ} \mathrm{C}$ to a constant weight.

\section{Statistical Analysis}

The experimental design was a randomized complete block, with spring grazing date as the main plot and stocking rate as the split plot, with a nongrazed control. Grazing date and stocking rate were factor combinations of treatment. The analysis combined experiments across years. Years were considered to be fixed effects and blocks to be random effects. All data were analyzed using the Proc Mixed procedure (Littell et al. 1996). Spring herbage yield and plant density data were collected to characterize the available herbage, and their analysis did not include the stocking rate factor (split plot). Use, percentage of plants grazed, and summer yield data included both grazing date and stocking rate factors. Regression analyses were used to evaluate relationships between defoliation and grazing pressure (SAS Institute Inc 1985). For summer yield data, contrasts were written to test for linear and quadratic effects of spring grazing date and stocking rate and for differences between the control and grazed treatments. Because of the inherent variability associated with grazing studies on rangeland ecosystems, treatment effects were considered to be significant at $P \leq 0.1$ for all analyses.

\section{RESULTS AND DISCUSSION}

\section{Spring Herbage Yield}

Yield of current-year herbage averaged $114 \mathrm{~kg} \cdot \mathrm{ha}^{-1}$ on 10 April and increased to 236 and $472 \mathrm{~kg} \cdot \mathrm{ha}^{-1}$ on 1 May and 22 
Table 1. Yield (mean $\pm \mathrm{SE}$ ) and percentage composition of current-year and residual herbage at 3 spring grazing dates on upland Sandhills range during the years 2000 and 2001.

\begin{tabular}{|c|c|c|c|c|c|c|c|}
\hline \multirow[b]{2}{*}{ Species or group } & \multicolumn{4}{|c|}{ Yield $\left(\mathrm{kg} \cdot \mathrm{ha}^{-1}\right)$} & \multicolumn{3}{|c|}{ Composition (\%) } \\
\hline & $10 \mathrm{Apr}$ & 1 May & 22 May & SE & $10 \mathrm{Apr}$ & 1 May & 22 May \\
\hline Sedge spp. & $41^{\mathrm{a}}$ & $75^{\mathrm{b}}$ & $96^{\mathrm{b}}$ & 8 & 36 & 22 & 20 \\
\hline Needleandthread & $25^{\mathrm{a}}$ & $57^{\mathrm{b}}$ & $96^{\mathrm{C}}$ & 10 & 22 & 24 & 20 \\
\hline Bluegrasses & 29 & 33 & 44 & 7 & 26 & 14 & 9 \\
\hline Prairie junegrass & $2^{\mathrm{a}}$ & $14^{\mathrm{b}}$ & $20^{b}$ & 3 & 2 & 6 & 4 \\
\hline Western wheatgrass & 6 & 6 & 9 & 3 & 5 & 3 & 2 \\
\hline Scribner's panicum & $4^{\mathrm{a}}$ & $6^{\mathrm{a}}$ & $16^{b}$ & 3 & 4 & 3 & 3 \\
\hline Other cool-season grasses & $3^{\mathrm{a}}$ & $10^{\mathrm{ab}}$ & $17^{\mathrm{b}}$ & 3 & 3 & 4 & 4 \\
\hline Prairie sandreed & $0^{\mathrm{a}}$ & $6^{\mathrm{b}}$ & $64^{\mathrm{C}}$ & 4 & 0 & 3 & 14 \\
\hline Other warm-season grasses & $0^{\mathrm{a}}$ & $9^{b}$ & $70^{c}$ & 3 & 0 & 4 & 15 \\
\hline Forbs & $3^{a}$ & $20^{b}$ & $40^{c}$ & 5 & 3 & 8 & 8 \\
\hline Total current-year herbage & $114^{\mathrm{a}}$ & $236^{\mathrm{b}}$ & $472^{\mathrm{c}}$ & 18 & 100 & 100 & 100 \\
\hline Total cool-season ${ }^{1}$ & $111^{\mathrm{a}}$ & $201^{b}$ & $298^{c}$ & 16 & 100 & 93 & 69 \\
\hline Total warm-season grasses & $0^{\mathrm{a}}$ & $14^{\mathrm{b}}$ & $134^{\mathrm{C}}$ & 3 & 0 & 7 & 31 \\
\hline Residual $^{2}$ & $637^{\mathrm{a}}$ & $554^{\mathrm{ab}}$ & $510^{b}$ & 32 & - & - & - \\
\hline
\end{tabular}

${ }^{1}$ Total cool-season includes cool-season grasses and sedges. Forbs were not included in calculation of percentage composition for total cool- and warm-season components. ${ }^{2}$ Residual consisted of standing, previous-year herbage.

a,b,c Within species or group, yield means with unlike letters differ significantly $(P<0.1)$.

May, respectively $(P<0.01)$ (Table 1$)$. Averaged across dates, the sedges, needleandthread, and bluegrasses had the greatest herbage yields and, collectively, accounted for $68 \%$ of the total. Western wheatgrass, Scribner's panicum, prairie junegrass, and other cool-season grasses generally accounted for $6 \%$ or less of the total yield at any of the dates. Six-week fescue (Festuca octoflora Walt.) was the most common species in the other cool-season grasses group.

Most species or groups had increases in yield after 10 April. The exceptions were western wheatgrass and bluegrasses, which had yields that did not differ among dates. Bluegrasses had relatively high yield during the early spring and accounted for $26 \%$ of the total on 10 April. As expected, yield of warm-season grasses was extremely low until 22 May. Yield of warm-season grasses was $134 \mathrm{~kg} \cdot \mathrm{ha}^{-1}$ on $22 \mathrm{May}$, or $31 \%$ of the total graminoid yield.

Yields of sedges, total herbage, and total cool-season herbage were greater in the year 2000 than in the year 2001 $(P<0.03)$. Average yield of sedges in 2000 was $93 \mathrm{~kg} \cdot \mathrm{ha}^{-1}$, compared to $48 \mathrm{~kg} \cdot \mathrm{ha}^{-1}$ in 2001 . Total current-year herbage was $329 \mathrm{~kg} \cdot \mathrm{ha}^{-1}$ in 2000 and $219 \mathrm{~kg} \cdot \mathrm{ha}^{-1}$ in 2001 . For total cool-season herbage, the yield was $242 \mathrm{~kg} \cdot \mathrm{ha}^{-1}$ in 2000 and $165 \mathrm{~kg} \cdot \mathrm{ha}^{-1}$ in 2001. On cool-season-dominated rangeland in North Dakota, Frank and Hofmann (1989) found a strong relationship between accumulated GDD and rate of morphological development of several species. However, those authors suggested that the quantity of forage produced primarily was a function of available soil moisture and nutrients. In the present study, the difference in herbage yield between years may have been related to GDD. Total precipitation for the period from 1 March to 22 May was $69 \%$ and $45 \%$ above the longterm mean in 2000 and 2001, respectively. However, accumulated GDD on 22 May was $10 \%$ greater in 2000 than in 2001 (Fig. 2). Year differences in soil temperature and solar radiation

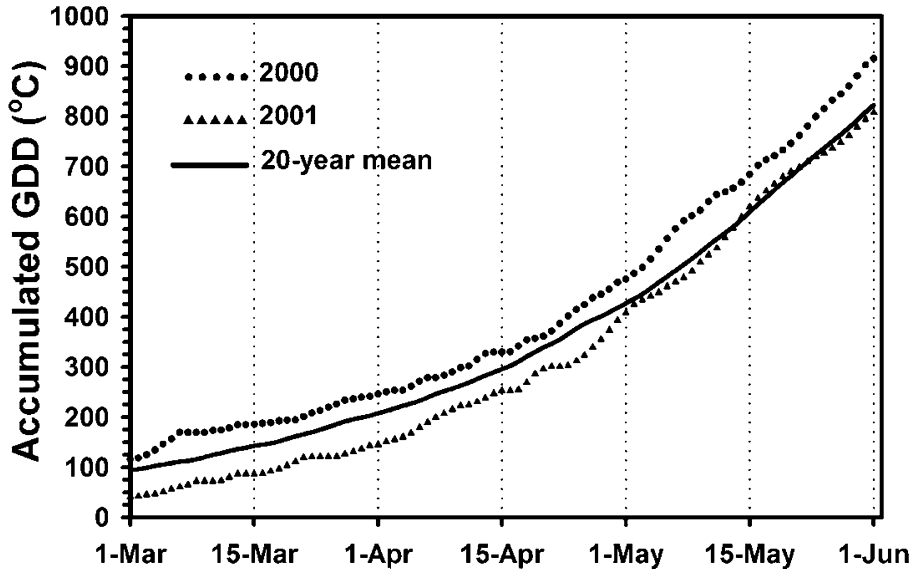

Figure 2. Accumulated growing degree-days (GDD; base, $0^{\circ} \mathrm{C}$ ) during the years 2000 and 2001 and the 20-year mean at the Gudmundsen Sandhills Laboratory near Whitman, Nebraska.

from 1 March to 22 May also support this conclusion. Soil temperature (depth, $10 \mathrm{~cm}$ ) averaged $2.4^{\circ} \mathrm{C}$ greater in 2000 than in 2001 , and total solar radiation $\left(\mathrm{cal} \cdot \mathrm{cm}^{-2}\right)$ was $4 \%$ greater in 2000 compared to 2001.

Averaged over both years and stocking rate levels, grazing pressure on 10 April, 1 May, and 22 May was 53, 25, and 13 AUD $\cdot \mathrm{Mg}^{-1}$, respectively. Although spring stocking rates were relatively low, averaging $14 \%$ of a moderate season-long rate, the grazing pressure on 10 April was high because of the low amount of current-year herbage. However, residual (prior-year) herbage in the paddocks averaged $567 \mathrm{~kg} \cdot \mathrm{ha}^{-1}$ during the spring grazing dates (Table 1). Grazing pressure at moderate stocking rates during the summer months range from 30 to 50 AUD $\cdot \mathrm{Mg}^{-1}$ (Cullan et al. 1999).

\section{Plant Density}

Sedge species had the greatest density, averaging 260 plants $\cdot \mathrm{m}^{-2}$, followed by needleandthread, with 13 plants $\cdot \mathrm{m}^{-2}$. Densities of sedge, needleandthread, prairie junegrass $\left(3\right.$ plants $\left.\cdot \mathrm{m}^{-2}\right)$, and western wheatgrass $\left(7\right.$ plants $\left.\cdot \mathrm{m}^{-2}\right)$ were similar among years and grazing dates $(P>0.15)$. Date, however, had a significant effect on density of Scribner's panicum and prairie sandreed $(P<0.01)$. Scribner's panicum density increased from 3 plants $\cdot \mathrm{m}^{-2}$ on 10 April to 6 plants $\cdot \mathrm{m}^{-2}$ on 1 May, but this density did not change between 1 May and 22 May. Emergence of prairie sandreed, the only warm-season species measured, began in early or mid-May and reached a density of 19 plants $\cdot \mathrm{m}^{-2}$ on 22 May.

\section{Plant Defoliation}

We found a significant interaction of year and grazing date for the percentage of sedge and needleandthread plants grazed $(P<0.01)$. More sedge plants were grazed on 1 May 2000 compared to 1 May 2001, and more needleandthread plants were grazed on 22 May 2001 compared to 22 May 2000. The cause of these interactions is not clear. Overall, a lower percentage of sedge and prairie junegrass plants were grazed on 10 April compared to 1 or 22 May $(P<0.01)$ (Table 2). Fewer needleandthread plants were grazed on 10 April and 1 May compared to 22 May. Stocking rate also had a significant effect on the percentage of sedge and needleandthread plants grazed. A lower 
Table 2. Percentage (mean $\pm \mathrm{SE}$ ) of plants grazed for spring grazing date and stocking rate treatments on upland Sandhills range in the years 2000 and 2001.

\begin{tabular}{|c|c|c|c|c|c|c|c|c|}
\hline \multirow[b]{2}{*}{ Species } & \multicolumn{4}{|c|}{ Grazing date } & \multicolumn{4}{|c|}{ Stocking rate $\left(A U D \cdot\right.$ ha $\left.^{-1}\right)$} \\
\hline & $10 \mathrm{Apr}$ & 1 May & 22 May & SE & 3 & 6 & 9 & SE \\
\hline & & & & $-(\%$ & & & & 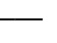 \\
\hline Sedges & $12^{\mathrm{a}}$ & $20^{\mathrm{b}}$ & $22^{b}$ & 1.5 & $10^{\mathrm{a}}$ & $20^{\mathrm{b}}$ & $24^{\mathrm{b}}$ & 1.5 \\
\hline Needleandthread & $24^{\mathrm{a}}$ & $25^{\mathrm{a}}$ & $31^{\mathrm{b}}$ & 1.8 & $16^{\mathrm{a}}$ & $31^{b}$ & $32^{b}$ & 1.8 \\
\hline Prairie junegrass & $5^{\mathrm{a}}$ & $20^{\mathrm{b}}$ & $15^{\mathrm{b}}$ & 2.8 & $9^{a}$ & $17^{\mathrm{a}}$ & $13^{\mathrm{a}}$ & 2.8 \\
\hline Western wheatgrass & $12^{\mathrm{a}}$ & $19^{a b}$ & $25^{\mathrm{b}}$ & 3.6 & $14^{\mathrm{a}}$ & $28^{\mathrm{b}}$ & $14^{\mathrm{a}}$ & 3.6 \\
\hline Scribner's panicum & $<1^{\mathrm{a}}$ & $2^{\mathrm{a}}$ & $13^{b}$ & 1.0 & $3^{\mathrm{a}}$ & $4^{a}$ & $7^{\mathrm{b}}$ & 1.0 \\
\hline Prairie sandreed & $0^{\mathrm{a}}$ & $0^{\mathrm{a}}$ & $15^{\mathrm{b}}$ & 0.9 & $2^{\mathrm{a}}$ & $5^{b}$ & $7^{\mathrm{b}}$ & 0.9 \\
\hline
\end{tabular}

percentage of plants were grazed at the $3 \mathrm{AUD} \cdot \mathrm{ha}^{-1}$ stocking rate compared to the 6 or $9 \mathrm{AUD} \cdot \mathrm{ha}^{-1}$ rate $(P<0.01)$. Fewer western wheatgrass plants were grazed on 10 April compared to 22 May $(P=0.03)$ (Table 2$)$. Inconsistent with results for the other species, western wheatgrass had a greater percentage of plants grazed at the $6 \mathrm{AUD} \cdot \mathrm{ha}^{-1}$ stocking rate compared to the 9 AUD $\cdot \mathrm{ha}^{-1}$ rate. Scribner's panicum had a lower percentage grazed on 10 April and 1 May compared to 22 May. Prairie sandreed did not have substantial emergence and yield until 22 May, at which time an average of $15 \%$ of the tillers were grazed. The short stature of the cool-season graminoids may have been a factor in the lower percentage of grazed plants on 10 April and 1 May compared to 22 May. Measurements taken for development of height-weight curves indicated an average height of $5 \mathrm{~cm}$ for both sedge and needleandthread on 10 April. By 1 May, average heights of sedges and needleandthread were 10 and $11 \mathrm{~cm}$, respectively. By 22 May, the average height of sedges was $14 \mathrm{~cm}$, and the average height of needleandthread was $35 \mathrm{~cm}$.

We also found a significant linear relationship between the percentage of needleandthread $\left(r^{2}=0.77\right)$ and sedge $\left(r^{2}=0.29\right)$ plants grazed and grazing pressure on 22 May $(P<0.02)$ (Fig. 3). For needleandthread, each 2 AUD $\cdot \mathrm{Mg}^{-1}$ increase in grazing pressure resulted in an approximately 5.3percentage unit increase in plants grazed. The relationship also was significant for needleandthread on 10 April and 1 May, but the $r^{2}$ values were only 0.22 and 0.23 , respectively. Grazing pressure also affected the percentage of prairie junegrass and prairie sandreed plants grazed on 22 May. The poor relationship between percentage of plants grazed and grazing pressure on 10 April and 1 May likely resulted from the short stature of the plants.

Defoliation of grazed needleandthread plants averaged $45 \%$ and was not affected by year, grazing date, or stocking rate $(P=0.39)$. Percentage defoliation of grazed sedge plants was only affected by grazing date; defoliation was greater on 10 April and 1 May $(43 \%)$ compared to 22 May $(35 \%, P<0.01)$. We found no significant, or only weak, relationships between percentage defoliation and grazing pressure for these 2 species when analyses were run by spring grazing date or across dates. Physiologically, damage to growing grasses generally is minimal until defoliation exceeds 50\%-60\% (Crider 1955; Launchbaugh 1967; Ryle and Powell 1975). Although the average level of
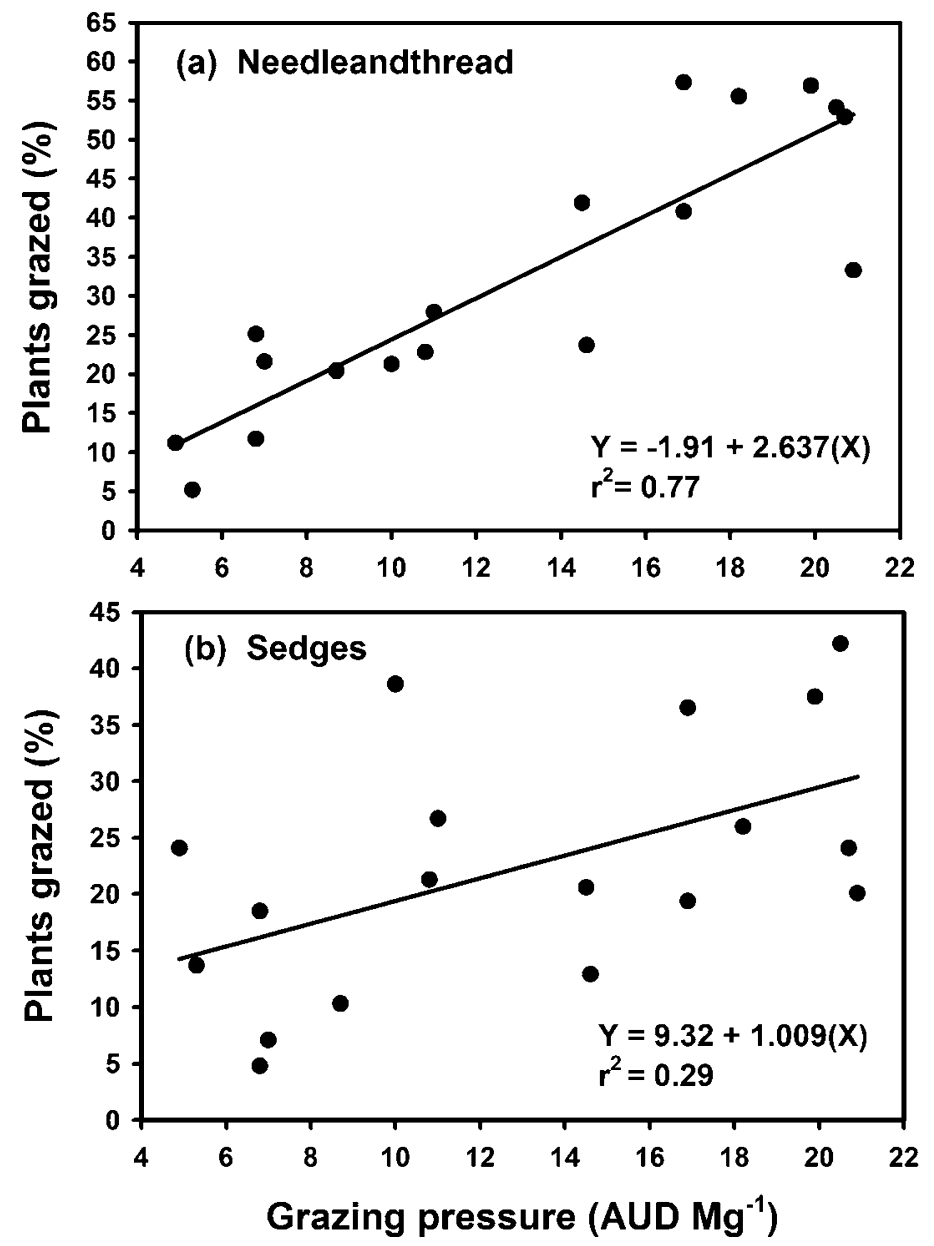

Figure 3. Effect of grazing pressure on percentage of $\mathbf{a}$, needleandthread and $\mathbf{b}$, sedge plants grazed on 22 May.

defoliation of grazed needleandthread and sedge plants was $45 \%$ or less, $52 \%$ of needleandthread and $39 \%$ of sedge plants were assigned to grazed-class $3(41 \%-70 \%$ use) or grazed-class 4 ( $>70 \%$ use) at the time of sampling. Many of the plants in these 2 categories likely were impacted negatively by defoliation.

Overall, use of sedges and needleandthread for the paddock population averaged $3.5 \%$ and $10.5 \%$, respectively. Both grazing date and stocking rate had a significant effect on use of these species $(P<0.01)$. For sedges, use on 10 April $(2.3 \%)$ was less than use on 1 May or 22 May (4.0\%). Needleandthread use on 10 April (7.6\%) was less than use on 1 May or 22 May (11.9\%). Use of sedges was significantly greater at the 6 and 9 AUD $\cdot \mathrm{ha}^{-1}$ stocking rates $(4.3 \%)$ compared to use at the $3 \mathrm{AUD} \cdot \mathrm{ha}^{-1}$ rate $(1.8 \%, P<0.01)$. Similarly, needleandthread use was $11.9 \%$ for the 6 and 9 AUD $\cdot$ ha $^{-1}$ stocking rates, compared to $7.6 \%$ for the 3 AUD $\cdot$ ha $^{-1}$ rate. Although sedges and needleandthread had similar yields at the 3 grazing dates (Table 1), cattle apparently selected for the larger tussock growth form of needleandthread rather than the small tussocks or individual tillers of sedges.

The relationship between use and grazing pressure was significant $(P<0.01)$, but only on 22 May (Fig. 4). For needleandthread and sedges, each 2 AUD $\cdot \mathrm{Mg}^{-1}$ increase in grazing pressure resulted in a 1.2 - and 0.7 -percentage unit increase in use, respectively. Grazing pressure appeared to have little effect on use at the 2 early grazing dates, especially on 10 April, when grazing 

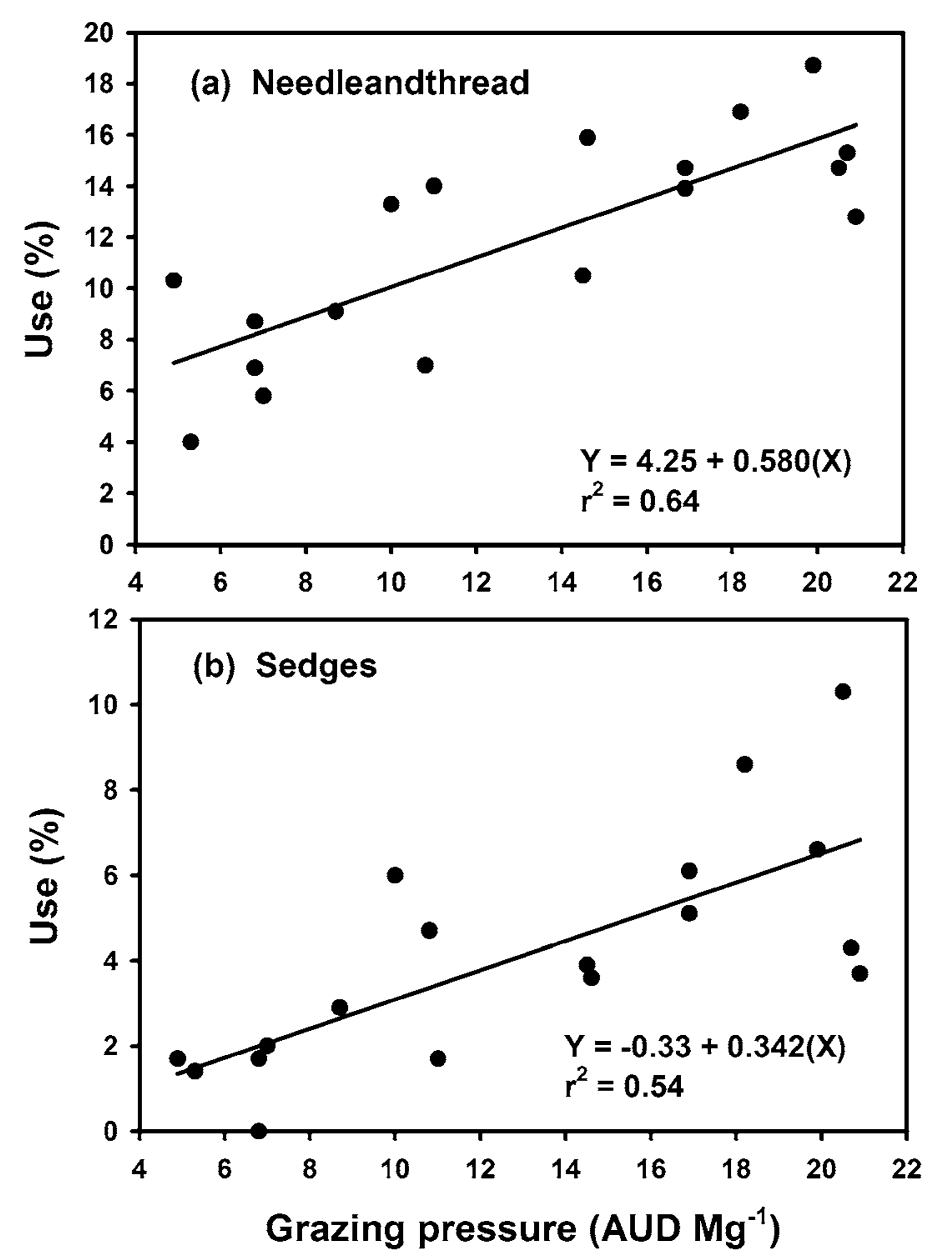

Figure 4. Effect of grazing pressure on paddock use of $\mathbf{a}$, needleandthread and $\mathbf{b}$, sedges on 22 May.

pressure was the greatest (53 AUD $\cdot \mathrm{Mg}^{-1}$ ) and use was the least. With low use of current-year herbage, cattle likely consumed residual herbage in an attempt to meet intake requirements (Wallace 1984), particularly on 10 April and, to a lesser extent, on 1 May. Residual herbage in our paddocks averaged 578 $\mathrm{kg} \cdot \mathrm{ha}^{-1}$ (Table 1). Although use was not measured on prairie junegrass, Scribner's panicum, western wheatgrass, or prairie sandreed, the percentage of plants grazed of those species generally was less than that of sedges and needleandthread
(Table 2). This suggests that the use levels of these species likely were similar to or less than the use levels observed for sedges and needleandthread. In addition, visual observations of the height of prairie junegrass and western wheatgrass indicated a similar height of sedges and needleandthread on all dates. Scribner's panicum, which was a later-emerging, cool-season species, was consistently shorter at all dates. Prairie sandreed tillers that had emerged by 22 May were shorter than all other species except Scribner's panicum.

\section{Summer Herbage Yield}

Total herbage yield on 18 June and 15 August was greater in the year 2001 than in the year $2000(P<0.03)$. Precipitation likely was the primary factor associated with the difference. In 2001, cumulative plant-year precipitation was $37 \%$ greater by 1 August compared to that in 2000. April and July were particularly wet months in 2001, when more than twice the long-term mean precipitation was recorded (Fig. 1).

Spring grazing date had a significant quadratic effect on yield of cool-season graminoids and total herbage on 18 June $(P<0.01)$ (Table 3$)$. Total yield was greatest when paddocks were grazed on 10 April $\left(1130 \mathrm{~kg} \cdot \mathrm{ha}^{-1}\right)$ and declined to 880 and $920 \mathrm{~kg} \cdot \mathrm{ha}^{-1}$ when grazed on 1 May and 22 May, respectively. This response was similar for the cool-season component, which is consistent with our findings regarding the use of needleandthread and sedges. Yield of forbs was greatest when grazed on 10 April and declined linearly on subsequent dates $(P=0.03)$. Residual herbage yield was lowest when grazed on 10 April and increased linearly on subsequent dates $(P=0.04)$. This indicates that cattle were consuming significant amounts of residual herbage on 10 April and 1 May, and it validates our observations regarding lower use of current-year herbage on those dates.

Spring grazing date did not affect yield of the warm-season component $(P=0.19)$. Warm-season grasses, primarily prairie sandreed, were not a substantial portion of the herbage until 22 May (Table 1). We found that an average of $15 \%$ of the prairie sandreed tillers were grazed at that date (Table 2); however, that level of use apparently did not affect yield on 18 June.

Stocking rate had a significant quadratic effect on warmseason and total herbage yield on 18 June $(P \leq 0.1)$ (Table 3$)$. Total yield was greatest when grazed at $3 \mathrm{AUD} \cdot \mathrm{ha}^{-1}(1030$ $\mathrm{kg} \cdot \mathrm{ha}^{-1}$ ) and declined to 940 and $970 \mathrm{~kg} \cdot \mathrm{ha}^{-1}$ when grazed at 6 and 9 AUD $\cdot \mathrm{ha}^{-1}$, respectively. The contrast of grazed treat-

Table 3. Mid-June yields $\left(\mathrm{kg} \cdot \mathrm{ha}^{-1}\right)$ (mean $\pm \mathrm{SE}$ ) of current-year cool-season graminoids, warm-season grasses, forbs, total herbage, and residual herbage for spring grazing date and stocking rate treatments on upland Sandhills range for the years 2000 and 2001.

\begin{tabular}{|c|c|c|c|c|c|c|c|c|c|c|c|c|c|c|c|}
\hline \multirow[b]{4}{*}{ Component } & \multirow{2}{*}{\multicolumn{10}{|c|}{$\longrightarrow\left(\mathrm{kg} \cdot \mathrm{ha}^{-1}\right)$}} & \multicolumn{5}{|c|}{ Contrasts $\left(P_{r}>F\right)$} \\
\hline & & & & & & & & & & & Grazing & Grazing & Stocking & Stocking & Grazed \\
\hline & \multicolumn{4}{|c|}{ Grazing date } & & & & & & SE of & date & date & rate & rate & \\
\hline & $10 \mathrm{Apr}$ & 1 May & 22 May & SE & 3 & 6 & 9 & SE & Control & control & linear & quadratic & linear & quadratic & control $^{1}$ \\
\hline Cool-season ${ }^{2}$ & 630 & 420 & 460 & 30 & 530 & 490 & 370 & 26 & 600 & 46 & 0.002 & 0.006 & 0.421 & 0.467 & 0.073 \\
\hline Warm-season & 340 & 320 & 350 & 11 & 360 & 320 & 330 & 11 & 330 & 20 & 0.289 & 0.136 & 0.106 & 0.096 & 0.592 \\
\hline Forbs & 160 & 130 & 110 & 14 & 150 & 120 & 140 & 10 & 160 & 18 & 0.027 & 0.855 & 0.513 & 0.192 & 0.224 \\
\hline Total & 1130 & 880 & 920 & 32 & 1030 & 940 & 970 & 30 & 1090 & 52 & 0.001 & 0.003 & 0.134 & 0.100 & 0.068 \\
\hline Residual & 250 & 340 & 390 & 42 & 360 & 340 & 310 & 32 & 290 & 56 & 0.043 & 0.331 & 0.135 & 0.908 & 0.410 \\
\hline
\end{tabular}

${ }^{1}$ Grazed treatments included all stocking rate by grazing date combinations.

${ }^{2} \mathrm{Cool}$-season component includes grass and sedge species. 
Table 4. Mid-August yields $\left(\mathrm{kg} \cdot \mathrm{ha}^{-1}\right)$ (mean $\pm \mathrm{SE}$ ) of current-year cool-season graminoids, warm-season grasses, forbs, total herbage, and residual herbage for spring grazing date and stocking rate treatments on upland Sandhills range for the years 2000 and 2001.

\begin{tabular}{|c|c|c|c|c|c|c|c|c|c|c|c|c|c|c|c|}
\hline \multirow[b]{4}{*}{ Component } & & & & & \multirow{2}{*}{\multicolumn{6}{|c|}{ Stocking rate $\left(\mathrm{AUD} \cdot \mathrm{ha}^{-1}\right)$}} & \multicolumn{4}{|c|}{ Contrasts $\left(P_{r}>F\right)$} & \\
\hline & & & & & & & & & & & \multirow{3}{*}{$\begin{array}{l}\text { Grazing } \\
\text { date } \\
\text { linear }\end{array}$} & \multirow{3}{*}{$\begin{array}{c}\text { Grazing } \\
\text { date } \\
\text { quadratic }\end{array}$} & \multirow{3}{*}{$\begin{array}{l}\text { Stocking } \\
\text { rate } \\
\text { linear }\end{array}$} & \multirow{3}{*}{$\begin{array}{l}\text { Stocking } \\
\text { rate } \\
\text { quadratic }\end{array}$} & \multirow{3}{*}{$\begin{array}{c}\text { Grazed } \\
\text { vs. } \\
\text { control }^{1} \\
\end{array}$} \\
\hline & \multicolumn{4}{|c|}{ Grazing date } & & & & & & SE of & & & & & \\
\hline & $10 \mathrm{Apr}$ & 1 May & 22 May & SE & 3 & 6 & 9 & SE & Control & control & & & & & \\
\hline Cool-season ${ }^{2}$ & 510 & 390 & 440 & 29 & 430 & 470 & 440 & 28 & 590 & 47 & 0.122 & 0.024 & 0.760 & 0.305 & 0.013 \\
\hline Warm-season & 660 & 610 & 680 & 36 & 710 & 600 & 650 & 36 & 580 & 58 & 0.666 & 0.133 & 0.178 & 0.069 & 0.232 \\
\hline Forbs & 180 & 170 & 110 & 22 & 170 & 130 & 160 & 21 & 160 & 35 & 0.055 & 0.459 & 0.687 & 0.063 & 0.373 \\
\hline Total & 1350 & 1170 & 1240 & 36 & 1320 & 1200 & 1250 & 36 & 1350 & 62 & 0.056 & 0.011 & 0.223 & 0.052 & 0.153 \\
\hline Residual & 180 & 280 & 320 & 29 & 280 & 250 & 250 & 26 & 250 & 45 & 0.007 & 0.438 & 0.337 & 0.658 & 0.827 \\
\hline
\end{tabular}

${ }^{1}$ Grazed treatments included all stocking rate by grazing date combinations.

${ }^{2}$ Cool-season component includes grass and sedge species.

ments versus the control was significant for cool-season and total yield $(P \leq 0.07)$. Cool-season yield on grazed paddocks $(500$ $\left.\mathrm{kg} \cdot \mathrm{ha}^{-1}\right)$ was less than the control value $\left(600 \mathrm{~kg} \cdot \mathrm{ha}^{-1}\right)$. Total herbage yield on grazed paddocks averaged $980 \mathrm{~kg} \cdot \mathrm{ha}^{-1}$, compared to $1090 \mathrm{~kg} \cdot \mathrm{ha}^{-1}$ in the control. Consumption by the grazing animals probably contributed to the observed response. Averaged across stocking rates, the estimated amount of dry matter consumed $\left(11.8 \mathrm{~kg} \cdot\right.$ AUD $\left.^{-1}\right)$ would be approximately $71 \mathrm{~kg} \cdot \mathrm{ha}^{-1}$. Although we did not evaluate individual plant response to defoliation in the present study, other factors, including use level and phenological stage when defoliated, may have played a role. Brueland et al. (2003) reported that early defoliation of smooth bromegrass (Bromus enermis Leyss.) did not impart morphological or developmental delays on the sward as a whole. Other research has shown that defoliation after the rapid-growth phase or during stem elongation will negatively affect subsequent yield (McLean and Wilkeem 1985; Mousel et al. 2003). In general, the cool-season grasses on our study site were beginning stem elongation in early May, and they were in the boot stage or had emerged inflorescences on 22 May.

Many of the treatment effects observed on herbage yield on 18 June also were present on 15 August (Table 4). Spring grazing date had a significant quadratic effect on cool-season and total yield on 15 August $(P \leq 0.02)$. Total yield was greatest when paddocks were grazed on 10 April $\left(1350 \mathrm{~kg} \cdot \mathrm{ha}^{-1}\right)$ and declined to 1170 and $1240 \mathrm{~kg} \cdot \mathrm{ha}^{-1}$ when grazed on 1 May and 22 May, respectively. This response was similar for the cool-season component.

Stocking rate had a significant quadratic effect on warmseason, forb, and total herbage yields on 15 August $(P<0.07)$ (Table 4). Total yield was greatest when grazed at 3 AUD $\cdot \mathrm{ha}^{-1}$ $\left(1320 \mathrm{~kg} \cdot \mathrm{ha}^{-1}\right)$ and declined to 1200 and $1250 \mathrm{~kg} \cdot \mathrm{ha}^{-1}$ when grazed at 6 and $9 \mathrm{AUD} \cdot \mathrm{ha}^{-1}$, respectively. Cool-season yield in grazed treatments $\left(450 \mathrm{~kg} \cdot \mathrm{ha}^{-1}\right)$ was less than in the control $\left(590 \mathrm{~kg} \cdot \mathrm{ha}^{-1}, P=0.01\right)$. As discussed previously, we attribute grazing of cool-season species during the spring as the primary cause of reduced summer herbage yield.

\section{MANAGEMENT IMPLICATIONS}

Cool-season grasses and sedges can account for a substantial portion of the total herbage production on upland Sandhills range sites. Herbage yields and use of cool-season species was low in April. Cattle grazing on upland range at this time of year apparently depends largely on residual herbage from the previous growing season. Grazing in April, however, does not appear to affect herbage yield later in the growing season. Grazing in May results in greater use of cool-season species, and subsequent herbage yield will be reduced. The reduced yield in June and August is related to decreased yields of cool-season species; herbage production of warm-season grasses are largely unaffected by spring grazing at light to moderate stocking rates. Overall, grazing upland range in mid to late spring to meet the objectives of an extended grazing strategy would, in most cases, reduce forage availability later in the growing season. Spring grazing has advantages, however, because cool-season species are being consumed at a time when their stocking value is relatively high. In addition, quality and palatability of most species, such as needleandthread, decline substantially if grazing is delayed until late spring or early summer (Hodgson 1986; Nelson and Moser 1994).

\section{LITERATURE CITED}

Adams, D. C., R. T. Clark, S. A. Coady, J. B. Lamb, and M. K. Neilson. 1994. Extended grazing systems for improving economic returns from Nebraska Sandhills cow/calf operations. Journal of Range Management 47:258-263.

Adams, D., D. Clark, R. Sandberg, G. Carriker, T. Klopfenstein, and T. Milton. 2001. June versus March calving for the Nebraska Sandhills: production traits. In: University of Nebraska-Lincoln Beef Cattle Report MP76-A. p 8-9.

Bleed, A. S., and C. A. Flowerday. 1998. An atlas of the Sandhills. University of Nebraska-Lincoln. Resource Atlas No. 5b. 265 p.

Bragg, T. B., and A. A. Steuter. 1995. Mixed prairies of North American Great Plains. In: Transactions of the North American Wildlife and Natural Resource Conference. Washington, DC. p 335-338.

Brueland, B. A., K. R. Harmoney, K. J. Moore, J. R. George, and E. C. Brummer. 2003. Developmental biology of smooth bromegrass growth following spring grazing. Crop Science 43:1789-1796.

Coady, S. A., and R. T. Clark. 1993. Ranch management practices in the Sandhills of Nebraska: managing production. University of Nebraska-Lincoln, Agricultural Research Division Research Bulletin RB-318. 66 p.

Coyne, P. I., M. J. TrLicA, And C. E. Owensby. 1995. Carbon and nitrogen dynamics in range plants. In: D. J. Bedunah and R. E. Sosebee [eds.]. Wildland plants: physiological ecology and developmental morphology. Denver, CO: Society for Range Management. p 59-167.

CRIDER, F. J. 1955. Root-growth stoppage resulting from defoliation of grass. US Department of Agriculture Technical Bulletin 1102. Washington, DC. 23 p. 
Cullan, A. P., P. E. Reece, and W. H. Schacht. 1999. Early summer grazing effects on defoliation and tiller demography of prairie sandreed. Journal of Range Management 52:447-453.

Engel, R. K., J. T. Nichols, J. L. Dodd, and J. E. Brummer. 1998. Root and shoot responses of sand bluestem to defoliation. Journal of Range Management 51:42-46.

Frank, A. B., And L. Hofmann. 1989. Relationship among grazing management, growing degree-days, and morphological development for native grasses on the northern Great Plains. Journal of Range Management 42:199-202.

Great Plains Flora Association. 1986. Flora of the Great Plains. In: T. M. Barkley [ed.]. Lawrence, KS: University of Kansas Press. $1392 \mathrm{p}$.

HeADY, H. F. 1974. Theory of seasonal grazing. Rangeman's Journal 1:37-38.

Hermann, F. J. 1970. Manual of the Carices of the Rocky Mountains and Colorado Basin. Agricultural Handbook 374. Washington, DC: US Department of Agriculture Forest Service. 397 p.

Hodgson, J. 1986. Grazing behavior and herbage intake. In: J. Frame [ed.]. Grazing. Hurley, Burkes, England: British Grassland Society. p 51-64.

Launchbaugh, J. L. 1967. Vegetation relationships associated with intensity of summer grazing on a clayey upland site in the Kansas 20- to 24-inch precipitation zone. Kansas Agricultural Experiment Station Technical Bulletin 154. 24 p.

Littell, R. C., G. A. Milliken, W. W. Stroup, and R. D. Wolfinger. 1996. SAS system for mixed models. Cary, NC: SAS Institute, Inc. 633 p.

MANSKE, L. L. 1999. Defoliation applied at some phenological growth stages negatively affects grass plants. Report DREC 99-3013. Dickinson, ND: North Dakota State University, Dickinson Research and Extension Center Range Manage. $4 \mathrm{p}$.

McLean, A., ANd S. WilkeEm. 1985. Influence of season and intensity of defoliation on bluebunch wheatgrass survival and vigor in southern British Columbia. Journal of Range Management 38:21-26.

Mousel, E. M., W. H. SCHACht, AND L. E. Moser. 2003. Summer grazing strategies following early-season grazing of big bluestem. Agronomy Journal 95: 1240-1245.

Mullahey, J. J., S. S. Waller, and L. E. Moser. 1991. Defoliation effects on yield and bud and tiller numbers of two Sandhills grasses. Journal of Range Management 44:241-245.

Nelson, C. J., And L. E. Moser. 1994. Plant factors affecting forage quality. In: G. C. Fahey et al. [eds.]. Forage quality, evaluation, and utilization. Madison, WI: American Society of Agronomy, Crop Science Society of America, and Soil Science Society of America. p 115-142.

NoRTHUP, B. K. 1993. Utilization of native forages in the Nebraska Sandhills by yearling cattle [dissertation]. Lincoln, NE: University of Nebraska-Lincoln. 328 p.

Reece, P. E., J. E. Brummer, R. K. Engel, B. K. Northup, and J. T. Nichols. 1996. Grazing date and frequency effects on prairie sandreed and sand bluestem. Journal of Range Management 49:112-116.

Ryle, C. J. A., AND C. E. Powell. 1975. Defoliation and regrowth in the graminaceous plant: the role of current assimilate. Annals of Botany 39:297-310.

SAS Institute, Inc. 1985. SAS user's guide: statistics, version 5 edition. Cary, NC. $956 \mathrm{p}$.

Schmutz, E. M., G. A Holt, and C. C. Michaels. 1963. Grazed-class method for estimating forage utilization. Journal of Range Management 16: $54-60$.

Wallace, J. D. 1984. Some comments and questions on animal preferences, ecological efficiencies, and forage intake. In: National Research Council/ National Academy of Sciences: Developing Strategies for Rangeland Management. Boulder, CO: Westview Press. p 275-287. 